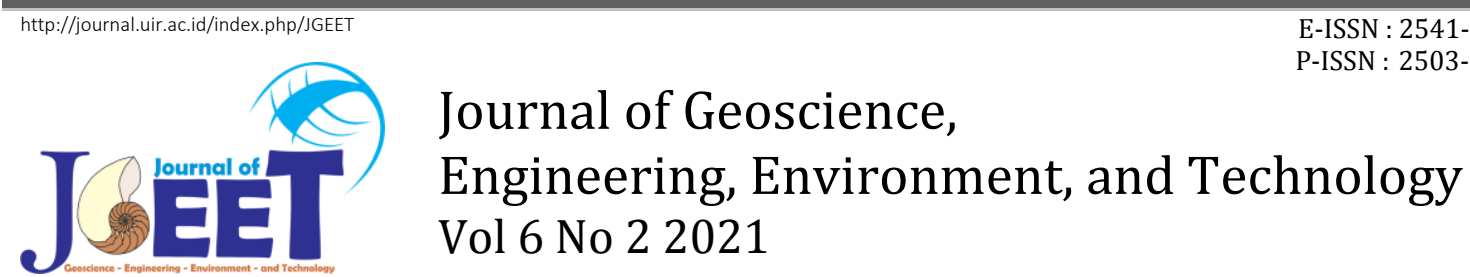

RESEARCH ARTICLE

\title{
Mapping of Sediment on the Waters Around Panjang Island, Banten Bay, Indonesia
}

\author{
Syawaludin A. Harahap ${ }^{1, *}$, Lintang P. S. Yuliadi ${ }^{1}$, Noir P. Purba ${ }^{1}$, Awal A. Aulia ${ }^{2}$ \\ ${ }_{1}^{1}$ Marine Science Department, Faculty of Fisheries and Marine Science, Universitas Padjadjaran, Jatinangor, 45363, Indonesia. \\ ${ }^{2}$ Study program of Marine Science, Faculty of Fisheries and Marine Science, Universitas Padjadjaran, Jatinangor, 45363, Indonesia. \\ * Corresponding author: syawaludin.alisyahbana@unpad.ac.id \\ Tel.:+62-813-8018-3431 \\ Received: May 05, 2020; Accepted: May 28, 2021. \\ DOI 10.25299/jgeet.2021.6.2.5057

\begin{abstract}
This study was conducted to map the surface sediment conditions in the waters around Panjang Island, Banten Bay. The survey method was conducted in February 2015 by taking sediment samples using a grab sampler at 15 stations. Sediment analysis was conducted to determine the grain size using the granulometry method which was then processed using the KUMMOD-SEL software to obtain the composition and texture of the sediment. The results of processing sediment samples at each station obtained that the grain size of sediments in the waters around Panjang Island ranged from -0.7 to 2.6 in the phi $(\varphi)$ scale. Sediment composition consists of sand and gravel, with sand dominance of $89.1 \%$. Sediment textural classification consists of only 4 categories i.e. very coarse sand, coarse sand, medium sand, and fine sand. In general, the pattern of sediment distribution follows the pattern of water depth, where fine sand occupies deeper areas. Meanwhile, medium sand dominates surface sediment distribution in the study area.
\end{abstract}

Keywords: Banten Bay, grain size, Panjang Island, phi $(\varphi)$ scale, sedimentation

\section{Introduction}

\subsection{Background}

Banten Bay is located on the north coast of Java Island, about $60 \mathrm{~km}$ west of Jakarta. Administratively, this area belongs to the northern coastal region of Serang Regency, Banten Province and geographically, is located at 5.90833 to 6.06667 southing and 106.06667 to 106.25000 easting connected to the Java Sea in the north and the west, south to east, the bay is bordered by the coastline of the mainland of Java Island. Topographically, Banten Bay waters are relatively shallow water with an average depth of $7 \mathrm{~m}$ with characteristics of muddy and sandy beaches and the composition of soil material consisting of mud, clay, silt, and sand (Boer et al., 2006). Sea currents generally have speeds reaching $35 \mathrm{~cm} / \mathrm{sec}$, indicating eastward direction during west monsoon and east monsoon current direction turning westward (Mustikasari et al., 2012; Satriadi, 2013; Wisha et al., 2015). Banten Bay has a relatively small beach wave that is less than $1 \mathrm{~m}$ high.

In this bay, there are approximately 12 islands, of which Panjang Island is the largest in the geographical position of 6.42167 to 6.47000 southing and 106.36917 to 106.42667 easting. Along the coast of Panjang Island to the surrounding waters in the Gulf of Banten there are coastal ecosystems and biological resources i.e. mangrove ecosystems, seagrass beds, and coral reefs. The potential damage to these ecosystems is very large due to environmental degradation. For example, the occurrence of changes in mangrove areas which are increasingly reduced due to coastal abrasion and land conversion (Anurogo et al., 2018; Arfando, 2008), the area of seagrass ecosystems have also diminished (Setiawan et al., 2012), even starting more than two decades ago (Kiswara, 1994), as well as coral reef ecosystems in most parts of this region are already in a damaged condition (Soedharma et al., 2017).

One important factor that plays a role in the degradation of ecosystems in the coastal environment is sedimentation originating from dredging and runoff. Runoff from land for example through rivers certainly brings suspended material from land especially sediments (e.g. mud and sand) (Kiswara, 1994). The speed of the sedimentation process that occurred in the Banten Bay waters was triggered by human activities such as sand/natural rock mining, hill leveling, and sea reclamation/dredging for industrial expansion and port development (Rahwawan et al., 2017).

Seen from its location, Panjang Island is strongly influenced by the condition of the waters current because the position of Panjang Island is directly facing the Java Sea to the north and at the same time is facing the river estuary flow from the west and south. River surface water carries tiny materials that then end up on the high seas and carried by ocean currents, thus forming sedimentation. Sediment accumulation and siltation in semi-enclosed areas (e.g. bay waters) are strongly influenced by high sedimentation rates and also due to weak ocean currents (Rahmawan et al., 2020). Changes in the morphology of the coast and the bottom of the waters occur as a result of the migration of sediment that takes place through the mechanism of erosion, transportation, and deposition. The sediments that are moved are sediments located on the surface of the bottom of the waters (Poerbondono and Djunarsjah, 2005). Sedimentation is closely related to geomorphic agents 
that work therein. The main geomorphic agents that cause or influence the processes and dynamics of coastal waters are waves, currents, and wind.

Transporting sediments through rivers to the ocean is an important pathway in the global geochemical cycle and a key component of the soil denudation system (Walling et al., 2003). Sediments that settle in the sea is a mixture of grains of various sizes (Bockelmann et al., 2018). The transportation and accumulation of sediments become a major factor in the process of silting and changes in the depth of a waters (Jumarang et al., 2012). Understanding sediment dynamics in complex environments is correct and important management in the process of mitigating or protecting ecosystems from the effects of human activities (Ferrarin et al., 2016).

The role of surface sediments at the bottom of the waters is quite important because it becomes a means of growth of aquatic benthic biota, as a nutrient provider and as a place for anchoring roots of marine vegetation such as seagrasses and mangroves (Atmadja and Sulistija,
1988). Furthermore, (Yuniarti et al., 2019) states that sedimentation that occurs at the bottom of the waters is highly correlated with uniformity and abundance index of macrozoobenthos. Another important function of the sediment is as a habitat for various types of bacteria that have an important role in the food chain cycle in coastal waters. However, sediment particles that are mobilized at a time from one place to another (Bracken et al., 2015), the sediment particles can be a carrier agent of pollutants. Furthermore, sediments carrying pollutants settle and accumulate at the bottom of waters originating from the mainland as well as those originating from surface waters such as oil spills, heavy metals, plastic waste and other toxic and dangerous substances (Arifin et al., 2012; Peng et al., 2017; Polidoro et al., 2017; Rochyatun and Rozak, 2008; Wasserman et al., 2016; Yu et al., 2018). Thus, sediment can also be used as an indicator of pollution because of its role as a "sink" for pollutants from the mainland.

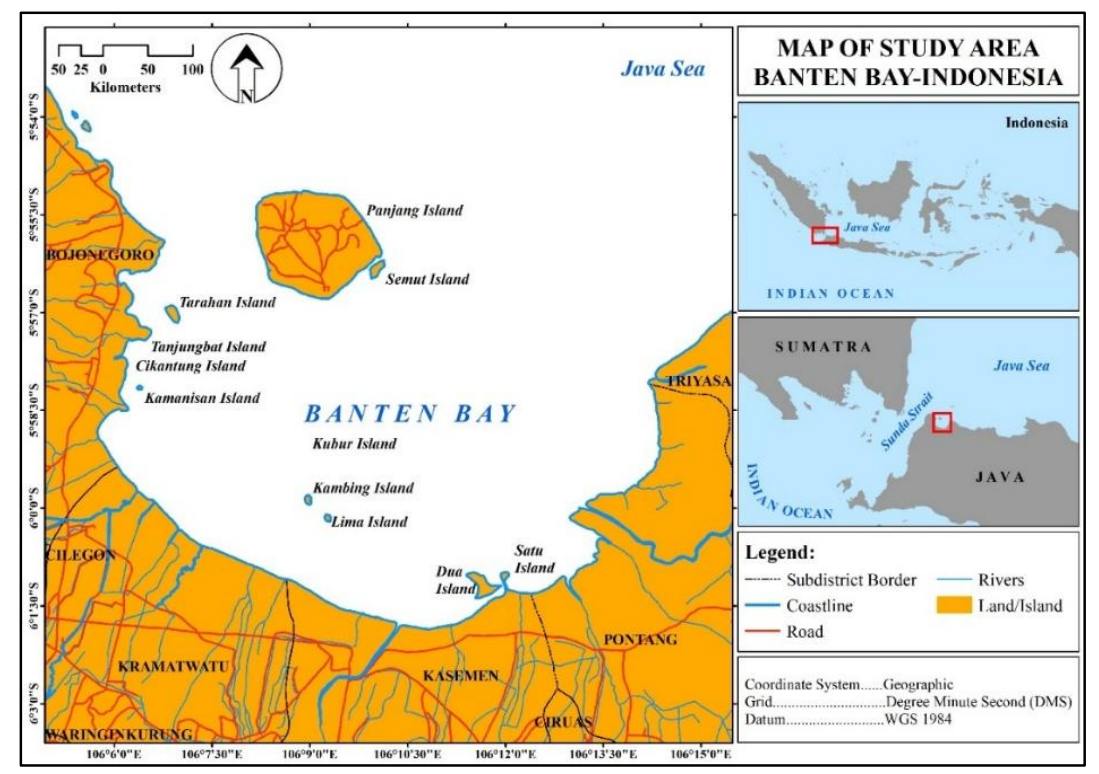

Fig. 1. Map of study the area and position of Panjang Island in Banten Bay.

\subsection{State of the art}

Studies related to sediment in Banten Bay is still limited. Research conducted by van den Bergh et al. (2003) and Boer et al. (2006) related to the deposition of sedimentary deposits generated only by the 1883 Krakatau eruption tsunami. Satriadi (2013) conducted a study to find out the distribution of suspended sediments associated with the construction of Bojonegara Harbor, Banten. A relatively new study is a study conducted by Rustam et al. (2018) to see the characteristics of surface sediment distribution and composition of organic matter and the rate of sedimentation. However, sediment samples taken are limited to represent coastal areas close to the mainland.

\subsection{The aim of the study}

To complement the information already available, this research is important to do. The purpose of this study is to map the surface sediment conditions around the waters of Panjang Island, Banten Bay. Studies on mapping sediment, both on a local and regional scale have been carried out and are very helpful in conducting analyzes and predictions about the distribution of sediment properties (Bockelmann et al., 2018).

\section{Data and method}

A field survey for sediment sampling was conducted in February 2015. Samples were taken using grab samplers at 15 stations using a purposive sampling technique, in which the determination of location points represented the central part of Banten Bay around Panjang Island waters. Surface sediment samples taken are in water depths ranging from 1.5-15 $\mathrm{m}$ (see Table 1 and Fig. 2). Sediment samples are then taken to the laboratory for washing, drying and sieving processes.

Sediment grain size analysis using granulometry method by sifting 100 gr of dry weight of sediment samples using the automatic sieve shaker tool. Sediment grain size data is then processed using the KUMMOD software package. This application software has been integrated with sediment classification/nomenclature (Folk, 1980) and is designed to determine the type of sediment based on grain size analysis (Susilohadi, 1986). The grain size and classification of sediment can be seen in Table 2. Classification is done based on the scale of 
Wentworth (1922) which is then converted to the phi $(\varphi)$ scale (W. C. Krumbein, 1934, 1938). Meanwhile, to determine the nomenclature of sediment type is based on Shepard's (1954) theory namely the sediment classification ternary diagram used and developed by Folk (1954), (1980); Blair and McPherson (1999) (see Fig. 3).

To achieve the objectives of this study, data related to the sediment grain size obtained were further analyzed by making a sediment distribution map. Mapping is done to make it easier to analyze data spatially with a geographic information system approach (GIS) using ArcGIS tool. This map distribution is done by interpolation technique using the inverse distance weighted (IDW) method. The IDW method provides more accurate interpolation results, for example, compared to the Kriging method (Pramono, 2008). This is because all the results using the IDW method provide values close to the minimum and maximum values of the sample data. Interpolation not only estimates the target variable at unsampled locations but also quantifies the remaining uncertainty (Bockelmann et al., 2018). The resulting map becomes information material to describe the condition of the sediment in the study area.

Table 1. Location coordinates for sediment sampling and water depth

\begin{tabular}{cccc}
\hline Station & Depth (meter) & Long. $\left({ }^{\circ}\right.$ East) & Lat. $\left({ }^{\circ}\right.$ South) \\
\hline 1 & -14.40 & 106.14005 & -5.94791 \\
2 & -5.70 & 106.14012 & -5.96695 \\
3 & -9.10 & 106.12860 & -5.95941 \\
4 & -6.80 & 106.13001 & -5.96096 \\
5 & -7.80 & 106.14003 & -5.98238 \\
6 & -4.80 & 106.12658 & -5.98207 \\
7 & -1.60 & 106.14339 & -5.99671 \\
8 & -7.50 & 106.17197 & -5.99481 \\
9 & -8.00 & 106.17290 & -5.97983 \\
10 & -8.40 & 106.16300 & -5.95843 \\
11 & -7.70 & 106.18631 & -5.95882 \\
12 & -4.00 & 106.19141 & -5.96025 \\
13 & -8.00 & 106.19115 & -5.97184 \\
14 & -8.60 & 106.18430 & -5.96346 \\
15 & -8.70 & 106.17184 & -5.95357 \\
\hline
\end{tabular}

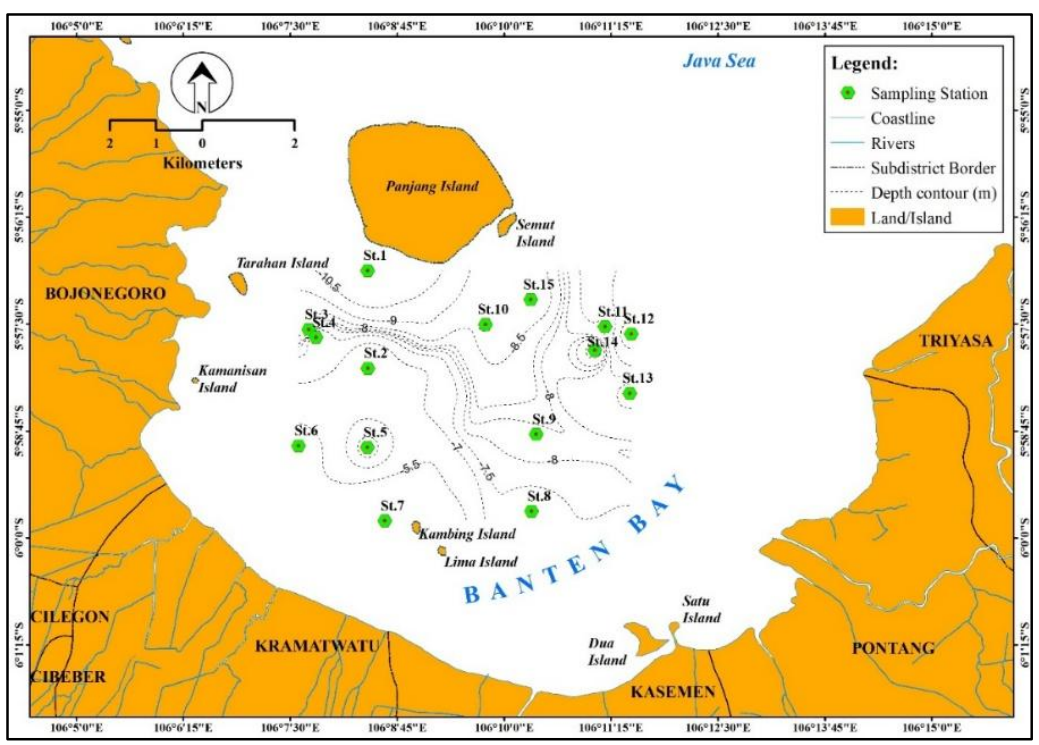

Fig. 2. Map location of sediment sampling stations. Station coordinates are recorded using a global positioning system (GPS), while depths are recorded using echo sounders. Depth contour (bathymetry) is constructed (interpolated) from the depth data at each station

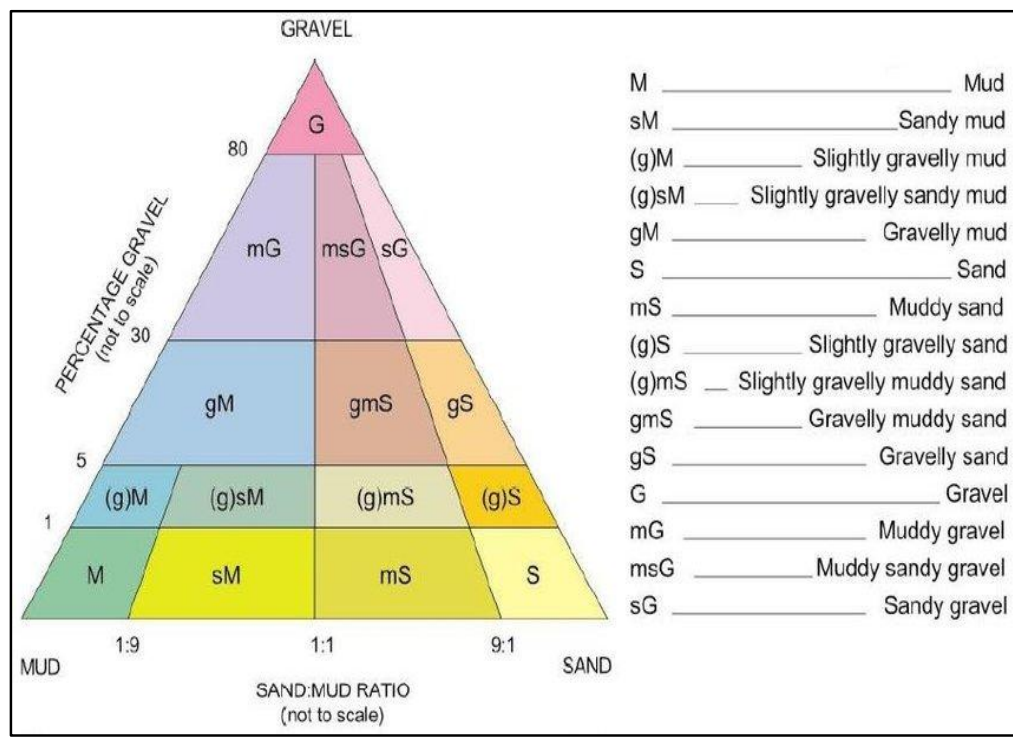

Fig. 3. Sediment classification ternary diagram Source: Derived from Folk (1954) 
Table 2. Sediment grain size and classification

\begin{tabular}{lllll}
\hline \multicolumn{2}{c}{ Grain size of sediment } & \multicolumn{1}{c}{$\begin{array}{c}\text { Aggregate name } \\
\text { (Wentworth class) }\end{array}$} & Unified Classification \\
\hline \multicolumn{1}{c}{ Phi $(\varphi)$ scale } & \multicolumn{2}{c}{ Millimeters } & \multicolumn{1}{c}{ Inches } & Boulder \\
\hline$<-8$ & $>256$ & $2.5-10.1$ & Cobble & \\
-6 to -8 & $64-256$ & $1.26-2.5$ & Very coarse gravel & Gravel \\
-5 to -6 & $32-64$ & $0.63-1.26$ & Coarse gravel & \\
-4 to -5 & $16-32$ & $0.31-0.63$ & Medium gravel & \\
-3 to -4 & $8-16$ & $0.157-0.31$ & Fine gravel & \\
-2 to -3 & $4-8$ & $0.079-0.157$ & Very fine gravel & \\
-1 to -2 & $2-4$ & $0.039-0.079$ & Very coarse sand & \\
0 to -1 & $1-2$ & $0.020-0.039$ & Coarse sand & \\
1 to 0 & $0.5-1$ & $0.010-0.020$ & Medium sand & \\
2 to 1 & $0.25-0.5$ & $0.0049-0.010$ & Fine sand & \\
3 to 2 & $0.125-0.250$ & $0.0025-0.0049$ & Very fine sand & Mud \\
4 to 3 & $0.0625-0.125$ & $0.00015-0.0025$ & Silt & \\
8 to 4 & $0.0039-0.0625$ & $3.8 \times 10^{-5}-1.5 \times 10^{-4}$ & Clay & \\
10 to 8 & $9.8 \times 10^{-4}-3.9 \times 10^{-3}$ & $3.8 \times 10^{-8}-3.8 \times 10^{-5}$ & Colloid & \\
20 to 10 & $9.5 \times 10^{-7}-9.8 \times 10^{-4}$ & &
\end{tabular}

Source: Combined from (Wentworth, 1922) and (W. C. Krumbein, 1938)

\section{Result}

\subsection{Sediment composition}

The sediment composition was related to the matrix soil texture (Foster et al., 1985). The analysis results related to the composition of the sediment at each station in the study site can be seen in Fig. 4. The sediment composition consists only of gravel and sand with an average composition of $10.9 \%$ for gravel compared to $89.1 \%$ for sand. Thus, the sand component is the predominant type of sediment, with percentages ranging from 49.9 - $99.8 \%$. This agrees with the results of the study by Rustam et al. (2018) although with a different percentage range. The largest percentage of sand texture is at station 10 with the sand composition of $99.8 \%$ compared to gravel with $0.2 \%$. Only at station 3 the percentage of gravel is greater than the percentage of sand that is $50.1 \%$ gravel and $49.9 \%$ sand. This result is different from research conducted by van den Bergh et al. (2003) which states that deposition in the bay is dominated by clayey silt.
The presence of coarse-sized sediments shows that the currents and waves in the area are relatively strong, coarse fractions are generally deposited in open areas associated with the high seas, while fine sediments deposited on currents and waves are completely calm. Oceanographic conditions in the southeast and southwest of Panjang Island with stronger currents because sedimentary coarse-sized (sand-gravel) sediments to quickly settle, while the fine fraction cannot settle and are carried away to quieter places. Clay and silt grains are usually deposited in waters with deep depth contours because of the very fine grain size that is easily trapped in the contours of the deep ocean floor (Karl, 2001). Coarse sand and gravel follow the law of the principle of deposition or erosion (force to lift). For finer grain deposition, what is needed is a current with a low speed and relatively deep depth (Setiady et al., 2015).

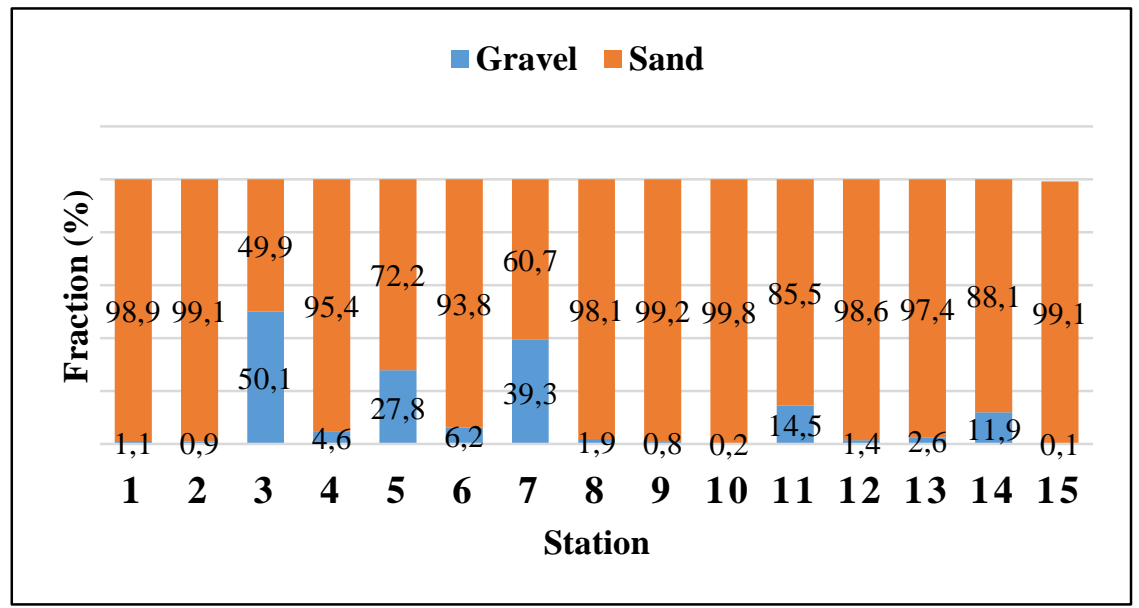

Fig. 4. Compositions of sediment fraction 


\subsection{Distribution of sediment}

In this study, the distribution of sediment is described based on the grain size and the classification of sediment. Grain size is the diameter of individual grains of sediment, or the lithified particles in clastic rocks. widely accepted and used as the practical standard for objective and detailed description of grain size needed for communicating observations and deductions about sediment and sedimentary rocks (Blair and McPherson, 1999). The results of processing sediment samples at each station obtained that the grain size of sediments in the waters around Panjang Island ranged from -0.7 to 2.6 in the phi scale. The smallest sediment grain size is 2.6 in phi units located at Station 9, located right in the middle of the bay (southeast of Panjang Island waters). Meanwhile, the largest sediment size is at station 3 with a phi value of -0.7 located in the southwestern waters of Panjang Island. We can also see that of the 15 sampling stations, there are 4 stations in the area with a grain size of $0-1$ phi scale, i.e. stations 4, 5, 7, and station 14 . Most of the distribution stations are in areas that have sediment grain size measuring 1 to 2 phi scale which is as many as 7 stations. The seven stations are sequences $1,2,6,8,11$,
12 , and 13 . In the meantime, there are 3 stations i.e. stations 9, 10, and station 15 . Meanwhile, only station 3 is in the area with sediment grain sizes of -1 to 0 phi scale (Fig. 5).

Stations $3,4,5,6$, and station 7 can be said to represent the area in the western part of the bay which is an area that is adjacent to the industrial area, fishing settlement, and port area. The process of developing the Bojonegoro port is possible to have brought relatively large size sediment grains to this area. Sediment at station 3 has the largest grain size, this is because the area at the sampling point is the location closest to the location of port development activities. Research conducted by Satriadi (2013), illustrates that the direction of sediment transport does indeed lead to this region. This is in line with the results of research conducted by Rustam et al. (2018) around the coast of Banten Bay, the texture of the sediments found reflects the existence of "reworked" sediment due to dredging during the construction of the Bojonegara port (port construction began in 2005).

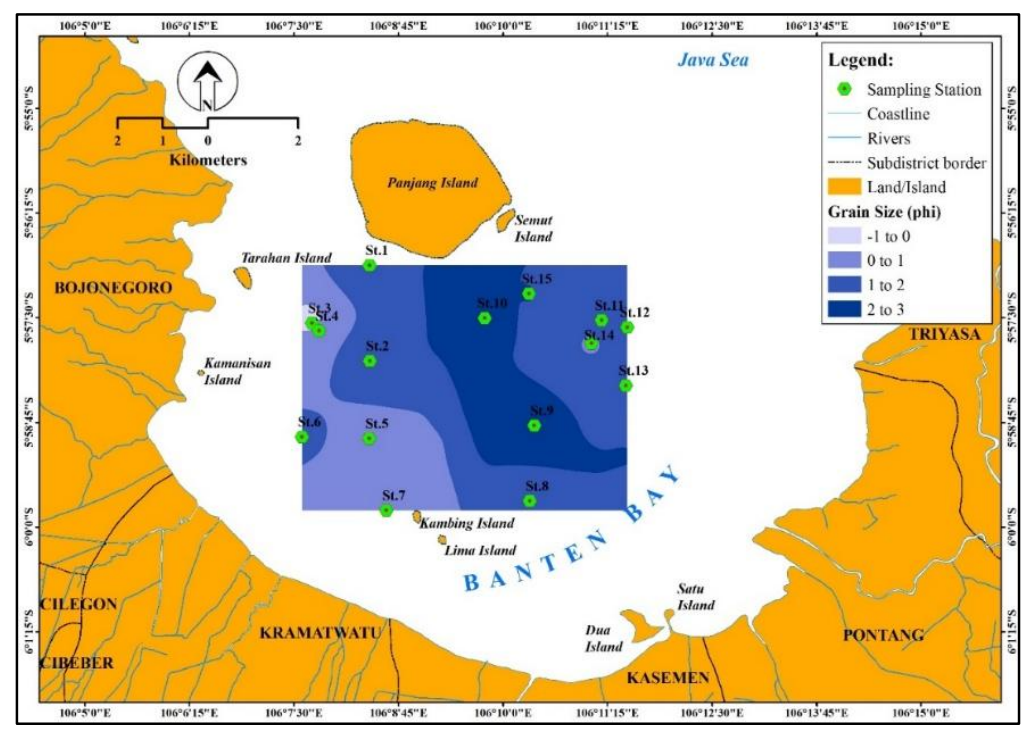

Fig. 5. Map of sediment grain size distribution pattern

The pattern of sediment grain size distribution is interpolated from the phi value at each station. The output value for a cell using IDW is limited to the range of the values used to interpolate. Because IDW is a weighted distance average, the average cannot be greater than the highest or less than the lowest input (Watson and Philip, 1985). The interpolation results are then reclassified based on the range of sediment grain size which can be seen in Table 2 so that it is obtained divided into four classes as seen in Fig. 5

The pattern of sediment grain size distribution shows that from the west to the center of the bay, the grain size of the sediment is getting smaller. Furthermore, from the middle part of the bay towards the east, the size of the sedimentary grain shows a trend of enlarging again. Large grains will settle to areas close to where the sediment was originally originated from, while small grains can be transported further. Fine sediments will be easier to move and tend to be swept faster than coarse size because they are transported in the form of suspension (Nugroho and Basit, 2014). Sedimentation of fine sediment grains can prevent the flow of waters in these locations tends to be quiet because the size of fine sediment grains is deposited in areas with slow current waters.

Further distribution analysis is related to the sediment class type. The size of sediment grains is key in determining sediment classification as shown in Table 2 . Sediment classification refers to the shape, size, and three-dimensional arrangement of the particles that make up sediment or sedimentary rock. Classification for sediment and sedimentary rocks is widely used because of its objectivity and practicality. This classification is a flexible polynomial scheme in which various sediment attributes are systematically listed. The roots of this scheme are the textural classes (e.g., gravel sand), which are qualified by other attributes in an adjective string (Blair and McPherson, 1999).

As the results of the sediment grain size analysis previously presented, it shows that the sediment at the study site is dominated by sand. The type of sand sediment that covers on the bottom of the water at the study site has a class type in the category of very coarse 
sand to fine sand with a grain size range of $1.00-0.025$ $\mathrm{mm}$. This shows that the sediment has undergone a deposition process. The deposition process is characterized by the deposition of fine to coarse-sized sediments (Nugroho and Basit, 2014).

Furthermore, if we look at Fig. 6, it can be seen that the pattern of distribution of this type of sand sediment type changes following the pattern of water depth contours. From the west to the middle of the waters have a distribution pattern from coarse sand to fine sand. In the eastern part, surface sediment is dominated by coarse sand. In the middle of Banten Bay, it is dominated by finer sand sedimentary types, with the right pattern between sediments with medium sand types. This is due to its location being protected by Panjang Island with waters deeper than its surroundings, while the type of sediment in the east is dominated by medium sand.

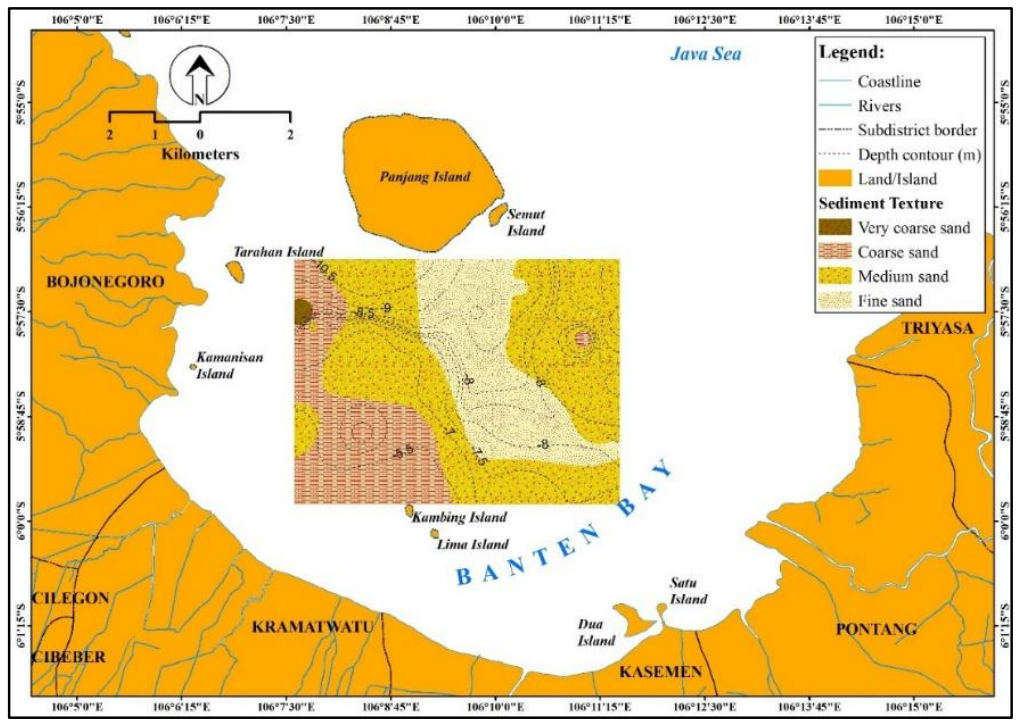

Fig. 6. Map of surface sediment texture distribution in the waters around Panjang Island, Banten Bay

\section{Discussion}

The difference and distribution of sediment grain size are influenced by several factors, such as distance from the coastline, distance from the source (river), source of sediment material, topography, and sediment transport mechanism (Abuodha, 2003). Referring to Gemilang et al. (2017), the more towards land or near river mouths and mangrove areas, the grain size of the sediment tends to be more subtle, while the grain size facing the open sea and further from the river mouth the grain size is coarser. This explains the reason why the size of sediment grains taken away relatively far from river mouths in waters around Panjang Island is greater than those taken around transitional waters from land to sea or in river mouths, as a study conducted by Rustam et al. (2018). The grain size of sediments tends to be more coarse taken at sample points far from land, indicating that sediment deposits in the area have relatively strong currents and waves because coarse fractions are generally deposited in open areas associated with open seas (Nugroho and Basit, 2014).

The sediment type obtained in this study only consists of gravel and sand, it is possible, because the sampling points of the station are located in the middle of the bay which is relatively far from the mainland, especially the distance from the river mouth. The pattern of direction and speed of the current is also a determining factor for the distribution of sediments in areas rather far from the mainland. Coastal areas close to the mainland to the shallow waters around them, fluvial processes, tides and waves, and their interactions are the main controlling factors in the process of sediment deposition. These factors have a significant impact on the patterns of sediment distribution and sedimentary facies produced, as well as the architecture and morphology of sedimentary units
(Ainsworth et al., 2011, 2008; Boyd et al., 1992; Galloway, 1975; Hoitink et al., 2017).

Current movements that occur in Banten Bay are generally generated by tidal forces as well as wind for surface currents (Wisha et al., 2015). At high tide or low tide, the speed of the current can increase so that the sediment that has been deposited can move to another place due to erosion and sedimentation (Triatmodjo, 1999). Although the position of Banten Bay is surrounded by many small islands which are a barrier to the entry of large energy into the inner bay waters and also makes it limited in water hydrodynamics, but the influence of strong currents results in a coarse fraction settling faster in the region. In general, the distribution of sediment type is distributed in groups from north to south with medium sand type dominating surface bottom sediments in the study area.

\section{Conclusions}

Based on the results of this study, it is known that the type of sediment distributed in the waters around Panjang Island, Banten Bay consists only of sand and gravel. Sand composition ranges from 49.9 - $99.8 \%$ and gravel ranges from $0.2 \%$ to $50.1 \%$. This means that most of the surficial sediment in the study area is sandy with an average composition of $89.1 \%$.

Sediment grain size ranges from -0.7 to 2.6 in the phi scale. Based on the sediment grain size, there are 4 texture categories i.e. very coarse sand, coarse sand, medium sand, and fine sand (measuring $1.00-0.025 \mathrm{~mm}$ ). Medium sand is a texture that dominates surface sediments in the waters around Panjang Island, Banten Bay.

Changes in sediment texture show a transverse distribution pattern (from west to east). In the western part, the sediment texture is more varied, however, it is more dominated by the coarse sand sediment texture, while in the eastern part it is dominated by medium sand type 
sediment texture. Meanwhile, the distribution of sediment types is distributed in groups in one type from north to south. In general, the pattern of sediment distribution follows the pattern of water depths, where the finer texture i.e. fine sand occupies deeper areas.

\section{Acknowledgments}

Thank to the Leaders and Staff at the Faculty of Fisheries and Marine Sciences, Universitas Padjadjaran who have provided support so that this study activity can be carried out well. Furthermore, thanks to KOMITMEN team that has helped in conducting field surveys and also to the referees for their constructive comments and suggestions.

\section{References}

Abuodha, J.O.Z., 2003. Grain size distribution and composition of modern dune and beach sediments, Malindi Bay coast, Kenya. J. African Earth Sci. 36, 4154. 5362(03)00016-2 https://doi.org/10.1016/S0899-

Ainsworth, R.B., Flint, S.S., Howell, J.A., 2008. Predicting coastal depositional style: influence of basin morphology and accommodation to sediment supply ratio within a sequence stratigraphic framework, in: Hampson, G.J., Steel, R.J., Burgess, P.M., Dalrymple, R.W. (Eds.), Recent Advances in Models of Siliciclastic Shallow-Marine Stratigraphy. SEPM Spec. Publ, pp. 237-263. https://doi.org/10.2110/pec.08.90.0237

Ainsworth, R.B., Vakarelov, B.K., Nanson, R.A., 2011. Dynamic spatial and temporal prediction of changes in depositional processes on clastic shorelines: Toward improved subsurface uncertainty reduction and management. Am. Assoc. Pet. Geol. Bull. 95, 267 297. https://doi.org/10.1306/06301010036

Anurogo, W., Lubis, M.Z., Khakhim, N., Prihantarto, W.J., Cannagia, L.R., 2018. The influence of sea tides on the dynamics of mangrove forest changes in Banten Bay. J. Kelautan: Indonesian J. Mar. Sci. Technol. 11, 130139. https://doi.org/10.21107/jk.v11i2.3804

Arfando, R., 2008. Changes of mangrove areas in Panjang Island, Serang Regency, Banten Province. Universitas Indonesia.

Arifin, Z., Puspitasari, R., Miyazaki, N., 2012. Heavy metal contamination in Indonesian coastal marine ecosystems: A historical perspective. Coast. Mar. Sci. 35, 227-233.

Atmadja, W.S., Sulistija, 1988. Some aspects of vegetation and habitat of benthic marine plants in Seribu Islands. Research Centre for Oceanography. Indonesian Institute of Science, Jakarta.

Blair, T.C., McPherson, J.G., 1999. Grain-size and textural classification of coarse sedimentary particles. J. Sediment. Res. 69, 6-19. https://doi.org/10.2110/jsr.69.6

Bockelmann, F., Puls, W., Kleeberg, U., Müller, D., Emeis, K., 2018. Mapping mud content and median grain-size of North Sea sediments - A geostatistical approach. Mar. Geol. 397, 60-71. https://doi.org/10.1016/j.margeo.2017.11.003

Boer, W., Van Den Bergh, G.D., De Haas, H., De Stigter, H.C., Gieles, R., Van Weering, T.C.E., 2006. Validation of accumulation rates in Teluk Banten (Indonesia) from commonly applied $210 \mathrm{~Pb}$ models, using the 1883 Krakatau tephra as time marker. Mar. Geol. 227, 263277. https://doi.org/10.1016/j.margeo.2005.12.002

Boyd, R., Dalrymple, R., Zaitlin, B.A., 1992. Classification of clastic coastal depositional environments. ,. Sed. Geol. 80, 139-150.

Bracken, L.J., Turnbull, L., Wainwright, J., Bogaart, P., 2015. Sediment connectivity: A framework for understanding sediment transfer at multiple scales. Earth Surf. Process. Landforms 40, 177-188. https://doi.org/10.1002/esp.3635

Ferrarin, C., Umgiesser, G., Roland, A., Bajo, M., De Pascalis, F., Ghezzo, M., Scroccaro, I., 2016. Sediment dynamics and budget in a microtidal lagoon - A numerical investigation. Mar. Geol. 381, 163-174 https://doi.org/10.1016/j.margeo.2016.09.006

Folk, R.L., 1980. Petrology of the sedimentary rocks, Geomorphology. Hemphill Publishing Company, Austin, Texas 78703. https://doi.org/10.1016/0169$555 \times(91) 90027-8$

Folk, R.L., 1954. The distinction between grain size and mineral composition in sedimentary-rock nomenclature. J. Geol. 62, 344-359.

Foster, G.R., Young, R.A., Neibling, W.H., 1985. Sediment composition for nonpoint source pollution analyses. Trans. Am. Soc. Agric. Eng. 28, 133-139. https://doi.org/10.13031/2013.32216

Galloway, W.E., 1975. Process framework for describing the morphologic and stratigraphic evolution of deltaic depositional systems, in: Broussard, M.L. (Ed.), Deltas, Models for Exploration. Houston Geological Society, Houston, TX, USA, pp. 87-98.

Gemilang, W.A., Wisha, U.J., Kusumah, G., 2017. Bed sediment distribution for identification of the coastal erosion in Brebes Subdistrict using granulometry analysis. J. Kelautan: Indonesian J. Mar. Sci. Technol. 10, 54-66. https://doi.org/10.21107/jk.v10i1.2156

Hoitink, A.J.F., Wang, Z.B., Vermeulen, B., Huismans, Y., Kästner, K., 2017. Tidal controls on river delta morphology. Nat. Geosci. 10, 637-645. https://doi.org/10.1038/ngeo3000

Jumarang, M.I., Muliadi, Ningsih, N.S., Hadi, S., 2012. Changes of the estuary waters bottom of the Kapuas River in West Kalimantan (Case study: January to April). Simetri 1, 42-46.

Karl, H.A., 2001. Sediment of the sea floor, in: Karl, H.A., Chin, J.L., Ueber, E., Stauffer, P.H., Hendley, J.W. (Eds.), Beyond the Golden Gate-Oceanography, Geology, Biology, and Environmental Issues in the Gulf of the Farallones. U.S. Geological Survey, Denver, USA, pp. 90-100.

Kiswara, W., 1994. The impact of the industrial area expansion on the decline of seagrass beds in Banten Bay, West Java, in: National Seminar in the Impact of Development on Coastal Areas. Serpong, pp. 1-11.

Mustikasari, E., Rustam, A., Adi, N.S., Purbani, D., 2012. Current movement in Banten Bay, in: National Seminar on Theory and Aplikasi of Marine Technology 2012.

Nugroho, S.H., Basit, A., 2014. Sediment distribution based on grain size analyses in Weda Bay, Northern Maluku. J. Ilmu dan Teknologi Kelautan Tropis 6, 229-240. https://doi.org/10.29244/jitkt.v6i1.8644

Peng, G., Zhu, B., Yang, D., Su, L., Shi, H., Li, D., 2017. Microplastics in sediments of the Changjiang Estuary, China. Environ. Pollut. 225, 283-290. https://doi.org/10.1016/j.envpol.2016.12.064

Poerbondono, E.D., Djunarsjah, E., 2005. Hydrographic survey, 1st ed. Refika Aditama, Bandung.

Polidoro, B.A., Comeros-Raynal, M.T., Cahill, T., Clement, C., 2017. Land-based sources of marine pollution: 
Pesticides, PAHs and phthalates in coastal stream water, and heavy metals in coastal stream sediments in American Samoa. Mar. Pollut. Bull. 116, 501-507. https://doi.org/10.1016/j.marpolbul.2016.12.058

Pramono, G.H., 2008. Accuracy of the IDW and kriging methods for interpolating the suspended sediment distribution in Maros, South Sulawesi. Forum Geogr. 22, 145158. https://doi.org/10.23917/forgeo.v22i2.4988

Rahmawan, G.A., Wisha, U.J., Gemilang, W.A., Ilham, I., Husrin, S., 2020. Accumulated sediment prediction based on bathymetry survey and hydrodynamics approach in Mandeh Coastal Bay, Pesisir Selatan Regency, West Sumatera. J. Kelautan Tropis 23, 105116. https://doi.org/10.14710/jkt.v23i1.6076

Rahwawan, G.A., Husrin, S., Prihantono, J., 2017. Bathymetry changes analysis in Serang District Waters caused by seabed sand exploitation. J. Ilmu dan Teknologi Kelautan Tropis. 9, 45-55.

Rochyatun, E., Rozak, A., 2008. The distribution of heavy metals in sediment of Jakarta Bay. Mar. Res. Indonesia 33 , 101-107. https://doi.org/10.14203/mri.v33i1.511

Rustam, A., Adi, N.S., Mustikasari, E., Kepel, T.L., Kusumaningtyas, M.A., 2018. Characteristics of sediment distribution and sedimentation rate in the Bay of Banten. J. Segara 14, 137-144. https://doi.org/10.15578/segara.v14i3.7351

Satriadi, A., 2013. Study of suspended sediment transport for development planning of Banten Bojonegara Port. Bul. Oseanografi Mar. 2, 68-77. https://doi.org/10.14710/buloma.v2i2.6942

Setiady, D., Kamiludin, U., Gerhaneu, N.Y., 2015. Type and sedimentary distribution on Papela Waters, RoteNdao, East Nusa Tenggara. J. Geol. Kelautan 13, 153163. https://doi.org/10.32693/jgk.13.3.2015.270

Setiawan, F., Harahap, S.A., Andriani, Y., Hutahaean, A.A., 2012. Seagrass change detection using remote sensing technology and its relation with carbon storage in Banten Bay. J. Perikanan dan Kelautan 3, 275-286.

Shepard, F.P., 1954. Nomenclature based on sand-silt-clay ratio. J. Sediment. Petrol. 24, 151-158.

Soedharma, D., Arafat, Khairudi, D., Panggarbesi, I.M., Sukmaraharja, Tarigan, A.R.S., Santoso, P., Hawis, M., Bramandito, A., Kusuma, H.A., 2017. Coral Reef in the waters of Tunda Island, Pamujan Besar Island and Pamujan Kecil Island, Banten Province, in: Cahyono, F.D., Simbolon, S. (Eds.), Proceeding of National Seminar on Ecosystem of Lada Bay Waters and Tunda Island 2017. LPSPL Serang, Serang, Banten, pp. 4550.

Susilohadi, 1986. Application program of sediment moment and nomenclature. Center for Research and Development of Marine Geology.

Triatmodjo, B., 1999. Coastal engineering. Beta Offset, Yogyakarta. van den Bergh, G.D., Boer, W., de Haas, H., van Weering, T.C.E., van Wijhe, R., 2003. Shallow marine tsunami deposits in Teluk Banten (NW Java, Indonesia), generated by the 1883 Krakatau eruption. Mar. Geol. 197, 13-34. https://doi.org/10.1016/S00253227(03)00088-4

W. C. Krumbein, 1938. Size frequency distributions of sediments and the normal phi curve. J. Sediment. Petrol. 8 , 84-90. https://doi.org/10.1306/d4269008-2b26-11d7$8648000102 \mathrm{c} 1865 \mathrm{~d}$

W. C. Krumbein, 1934. Size frequency distributions of sediments. J. Sediment. Petrol. 4, 65-77. https://doi.org/10.1306/d4268eb9-2b26-11d7$8648000102 \mathrm{c} 1865 \mathrm{~d}$

Walling, D.E., Owens, P.N., Carter, J., Leeks, G.J.L., Lewis, S., Meharg, A.A., Wright, J., 2003. Storage of sedimentassociated nutrients and contaminants in river channel and floodplain systems. Appl. Geochemistry 18, 195-220. https://doi.org/10.1016/S08832927(02)00121-X

Wasserman, J.C., Wasserman, M.A. V., Barrocas, P.R.G., Almeida, A.M., 2016. Predicting pollutant concentrations in the water column during dredging operations: Implications for sediment quality criteria. Mar. Pollut. Bull. 108, 24-32. https://doi.org/10.1016/j.marpolbul.2016.05.005

Watson, D.., Philip, G.M., 1985. A refinement of inverse distance weighted interpolation. Geo-Processing 2, 315-327.

Wentworth, C.K., 1922. A scale of grade and class terms for clastic sediments. J. Geol. 30, 377-392. https://doi.org/10.1086/622910

Wisha, U.J., Husrin, S., Prihantono, J., 2015. Hydrodynamics Banten Bay during transitional seasons (AugustSeptember). Ilmu Kelautan: Indonesian J. Mar. Sci. 20, 101-112. https://doi.org/10.14710/ik.ijms.20.2.101-112

Yu, X., Zhang, W., Liu, X., Lei, J., Lin, Z., Yao, Z., Yao, X., Jin, X., Yang, H., Huang, H., 2018. The distribution of and biodegradation impact on spilled oil in sediments from Dalian Bay, NE China. Mar. Pollut. Bull. 135, 1007-1015. https://doi.org/10.1016/j.marpolbul.2018.08.032

Yuniarti, Nurul Ihsan, Y., Harahap, S.A., Suhanda, D., 2019. Relationship of sedimentation rate to the structure of macrozoobenthos community on transitional in Ciletuh Bay, Sukabumi District, West Java. IOP Conf. Ser. Earth Environ. Sci. 406, 1-11. https://doi.org/10.1088/17551315/406/1/012024

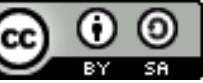

(C) 2021 Journal of Geoscience, Engineering, Environment and Technology. All rights reserved. This is an open access article distributed under the terms of the CC BY-SA License (http://creativecommons.org/licenses/by$\mathrm{sa} / 4.0 /)$. 